\title{
ALIMENTARY CANAL ANATOMY AND HISTOLOGY OF THE WORKER TERMITE NEOTERMES BOSEI
}

\author{
LEKSONOEKOPURANTOHARIPRABOWO, RIKARAFFIUDINAND \\ TARUNISRIPRAWASTI
}

\author{
Department of Biology, Faculty of Mathematics and Sciences, Bogor Agricultural University, \\ Jalan Ray a Pajajaran, Bogor, 16144 Indonesia
}

\begin{abstract}
As social insects, termites live in a colony that consist of reproductive (drone and queen), and non-reproductive (soldiers and workers) castes. Workers obtain their food directly from wood, humus, and other substances that contain cellulose. The objective of this study was to examine the alimentary canal of the Neotermes bosei workers. Observations of gut transverse section were carried out through the length, perimeter, and area of each alimentary canal region. The results showed that total length of $N$. bosei alimentary canal was $13.71+1.28 \mathrm{~mm}$. The canal was divided into fore-, mid, and hindgut which were 24,28 , and $48 \%$, respectively of the gut total length. Two types of alimentary canal epithelial cells were found, i.e. the squamous and transitional cells. Areas covered with thick muscular tissues were crop, proventriculus, and rectum. Proventriculus was characterized with six large dentitions. There was no gastric caeca in $N$. bosei midgut, which commonly occurred in chewing insect. Secretory cells .were observed at proventriculus and ventriculus regions. Cardiac valve was found at the anterior end of ventriculus. Area with the largest outer perimeter was the rectum pouch. Enteric valve had three internal folds.
\end{abstract}

Key words: drywood termites, alimentary canal, histology, Kalotermitidae

\section{INTRODUCTION}

Termites were classified into the Order of Isoptera, which consist of six families i.e. Mastotermitidae, Kalotermitidae, Hodotermitidae, Rhinotermitidae, Serritermitidae, and Termitidae (Krishna 1969). As social insects, termites live in a colony. Each colony comprises reproductive (drone and queen) and non-reproductive (worker and soldier) castes. Worker termites obtain their food directly from wood, humus and other materials that contain cellulose. Soldier castes obtain the food from the workers through trophalaxis (Stuart 1969). The ability of termites, particularly of the members of Kalotermitidae to digest the cellulose is due to the mutualistic symbiosis with the flagellate protist (Claveland 1925). Hence, the food digestion process in termites is different with that of most other insects (Tokuda et al. 2000; Inoue etal. 2000).

The alimentary canal is divisible into stomodeum (foregut), mesenteron (midgut) and proctodeum (hindgut). Digestion process occurred in the midgut (Dow 1986; Inoue et al. 2000), whereas hindgut is the most important part in food absorptions (Inoue et al. 2000).

Neotermes bosei (Figure 1) is classified into the family of Kalotermitidae (Ahmad 1965). $N$. bosei is known as damp wood termites, because it lives in the dry and living wood (Scheffrahn \& Su 1994). This species was selected for this current

$\overline{\text { Corresponding address : rika rafiudin.net.id }}$ 
termite histology study due to lack of information on Kalotermitidae alimentary canal . The objective of this study is to examine the anatomy and histology of the termite $N$. bosei worker alimentary canal.

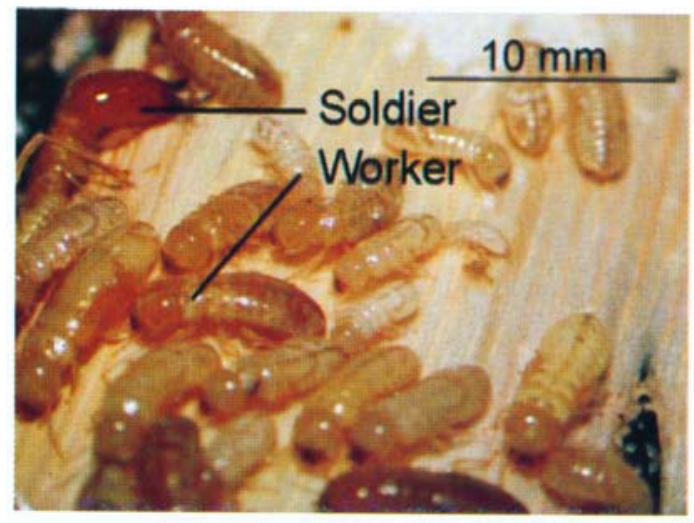

Figure 1. Soldier and worker castes of termite $N$. bosei

\section{MATERIALS AND METHOD}

\section{Neotermes bosei collection}

The $N$. bosei soldiers and workers imagoes were collected from the fishing shop in several traditional markets in Bogor, West Java (i.e. Pasar Anyar, Pasar Bogor, Pasar Ciawi, and Pasar Empang). The soldiers of $N$. bosei were needed for identification purpose up to species level.

\section{Observation of $N$. bosei alimentary canal}

\section{Length of Alimentary Canal}

Ten $N$. bosei alimentary canal were taken by dissectioning the lateral part of termite thorax and abdomen. Termite alimentary canal was observed under stereo microscope (Nikon FDX-35) and photographs were taken by using Nikon SMZ1000 camera. The photographs were digitized for analysing canal total length (crop up to anus), the length of fore-, mid-, and hindgut. The measurements were carried out with ImageJ sofware (http://rsb.info. nih.gov/ii).

\section{Diameter and the Cell Structure ofN. bosei Alimentary Canal}

Six series of serial transversal section of the canals were made through paraffin embedding method (thickness of $6 \mathrm{um}$ ). The sections were stained by using double staining of HaematoxylinEosin (HE). Photographs were taken with compound microscope (Olympus CH20) and Olympus DP 12 camera. Inner and outer peripheri 
(IP and OP), lumen area (LA), and gut area (GA) were measured by ImageJ sofware (http://rsb.info. nih.gov/ij).

\section{Embedding Block with Paraffin Method (Gray 1952)}

Neotermes bosei alimentary canals were fixed with Bouin fixative for two hours. Then, they were washed and dehydrated in series of ethanol i.e. 70, 80, $90 \%$, and absolute ethanol, 15 min for each step. For slide clearing it was immersed in Xylol for 1.5 hours. Infiltration paraffin step was performed for three times, each step in $45 \mathrm{~min}$ and subsequently stained with HE.

\section{RESULTS AND DISCUSSION}

\section{Foregut}

The TV. bosei foregut was a slender canal. The mean of length from the crop up to proventriculus is $3.32+0.57 \mathrm{~mm}$ (Figure 2).

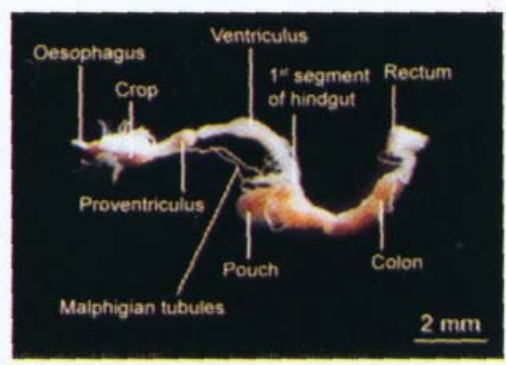

Figure 2. The alimentary canal of $N$. bosei worker termite

\section{Oesophagus}

Oesophagus was the canal that connected termite's pharynx and its crop. This region consisted of several layers, i.e. intima, squamous cells (at the lumen wall), columnar cell (at vili), and thin muscle layer (Figure 3). The IP, OP, LA, and GA values were listed in Table 1.

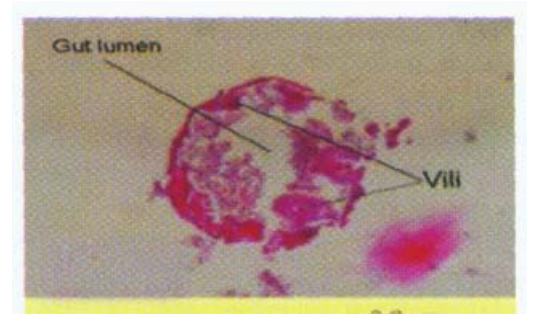

Figure 3. Oesophagus transversal section of $N$. bosei worker termite 


\section{Crop}

Neotermes bosei worker crop was divisible into three parts, i.e. the anterior, median, and posterior regions (Figure 4). The anterior crop had six large vili which covered almost the entire lumen. This region had intima layer, columnar epithelial cells (at the vili) and squamous epithelial cells (at the lumen wall), circular and longitudinal muscle cells. Mean of the IP, OP, LA and GA were listed in Table 1.
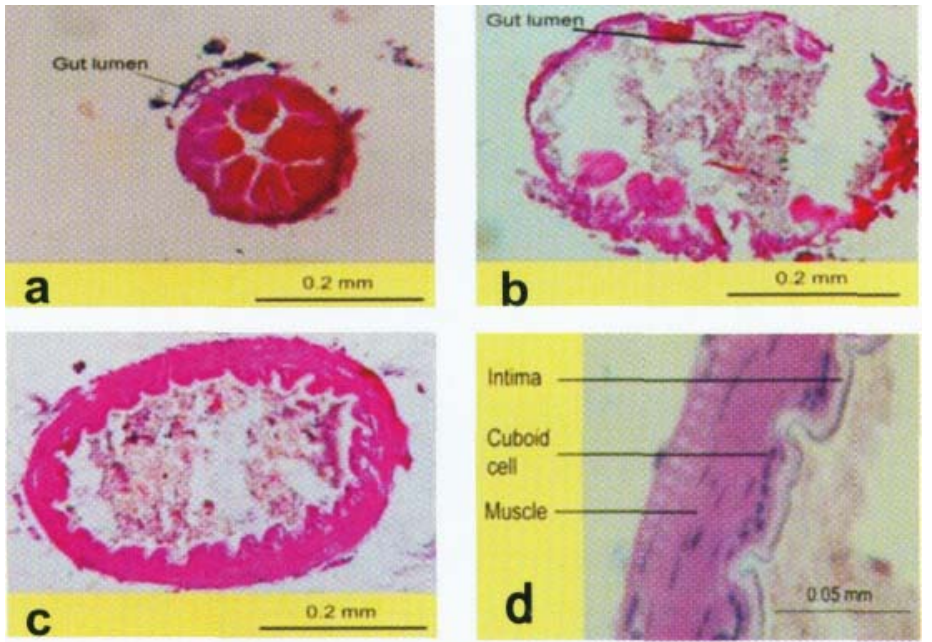

Figure 4. Crop transversal section of $N$. bosei worker termite (a) anterior, (b) median, (c) posterior region, (d) cell layers of the posterior crop

Table 1. Mean and standard deviation value of inner and outer peripheri (IP and OP), lumen area (LA), gut area (GA) of the worker termite $N$. bosei alimentary canal

\begin{tabular}{ccccc}
\hline Region & IP $(\mathrm{mm})$ & OP $(\mathrm{mm})$ & LA $\left(\mathrm{mm}^{2}\right)$ & GA $\left(\mathrm{mm}^{2}\right)$ \\
Oeso & $0.718 \pm 0.112$ & $0.666 \pm 0.046$ & $0.013 \pm 0.001$ & $0.003 \pm 0.0002$ \\
Cr1 & $0.948 \pm 0.283$ & $2.137 \pm 0.777$ & $0.015 \pm 0.007$ & $0.022 \pm 0.006$ \\
Cr2 & $1.731 \pm 0.104$ & - & - & - \\
Cr3 & $1.566 \pm 0.100$ & $2.140 \pm 0.225$ & $0.080 \pm 0.013$ & $0.041 \pm 0.006$ \\
Pv1 & $1.717 \pm 0.264$ & $2.391 \pm 0.350$ & $0.072 \pm 0.019$ & $0.071 \pm 0.010$ \\
Pv2 & $1.558 \pm 0.220$ & $2.429 \pm 0.841$ & $0.043 \pm 0.013$ & $0.092 \pm 0.027$ \\
V1 & $1.411 \pm 0.186$ & $0.717 \pm 0.187$ & $0.003 \pm 0.002$ & $0.104 \pm 0.023$ \\
V2 & $1.697 \pm 0.348$ & $1.434 \pm 0.433$ & $0.042 \pm 0.015$ & $0.104 \pm 0.040$ \\
P1 & $0.816 \pm 0.225$ & $0.710 \pm 0.167$ & $0.012 \pm 0.009$ & $0.021 \pm 0.004$ \\
P2 & $0.530 \pm 0.039$ & - & - & - \\
P3 & $3.859 \pm 1.807$ & - & - & - \\
P4 & $1.508 \pm 0.370$ & - & - & - \\
P5 & $2.036 \pm 0.569$ & - & - & - \\
\hline
\end{tabular}

Note:

Oeso= Oesofagus; $\mathrm{Crl}=$ anterior crop; Cr2= median crop; Cr3= posterior crop; Pvl= anterior Proventriculus; Pv2= posterior Proventriculus; $\mathrm{Vl}=$ anterior Ventriculus; $\mathrm{V} 2=$ posterior ventriculus; $\mathrm{Pl}=$ short channel; $\mathrm{P} 2=$ Enteric valve; $\mathrm{P} 3=$ Rectum pouch; $\mathrm{P} 4=$ Colon; $\mathrm{P} 5=$ Rectum; - = data not available 
Large number of vili covered the median region of the crops compared to that in the anterior region. Squamous epithelial cells in the median crop were shorter than those in the anterior (Figure 4B). The IP, OP, LA and GA values of median crop regions were higher than those in the anterior (Table 1). The posterior crop region contained the thickest muscle, intima layer, squamous epithelial cells, circular and longitudinal muscle layers (Figure 4C and 4D).

\section{Proventriculus}

Proventriculus was the last part of the foregut (Figure 2) consisted of anterior and the posterior regions (Figure 5a,b). Four dentitions were observed at the lumen wall at the anterior proventriculus region (Figure 5a), whereas six dentitions were found in the posterior region (Figure 5b).
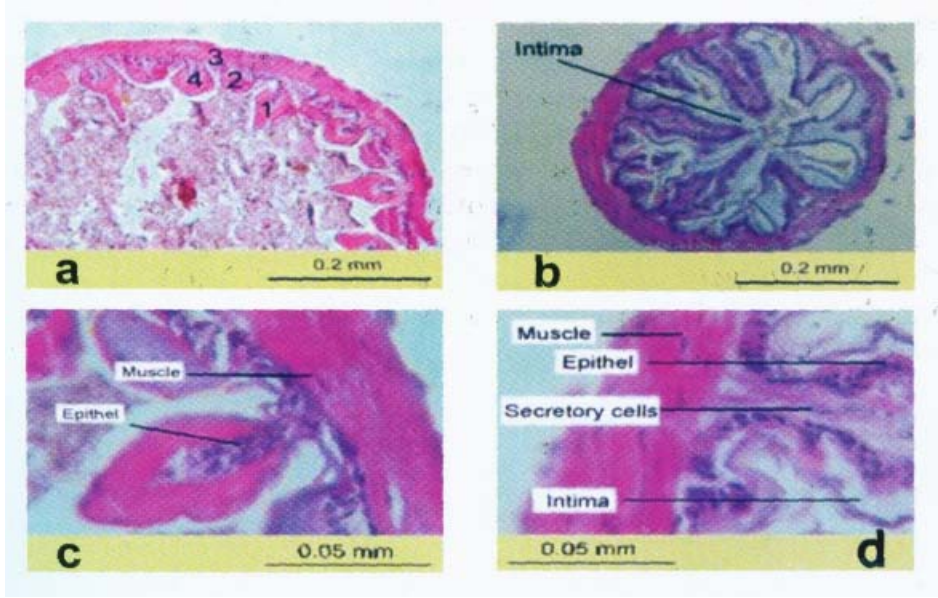

Figure 5. Proventriculus transversal section of .M bosei worker termite (a) anterior region, (b) posterior region, (c) cell layers composed the anterior region, (d) layers composition of the posterior region; 1,2,3,4 = dentition type in the anterior proventriculus

Proventriculus of $N$. bosei worker was covered by a thick intima, transitional epithelial cells, and a thick muscle layer (Figure 5c,d). Several secretory cells (Figure 5d) were also found in this region. They were characterized by a cluster of larger cells compared to the other epithelial cells surrounding them. Anterior and posterior proventriculus measurements were shown in Table 1.

As a chewing insect $N$. bosei worker has proventriculus canal (Miller 1965). The proventriculus occurred in the chewing insect such as moth larva Hofmannophila pseudospretella (Lepidoptera: Oecophoridae) (Gerard 2002) and beetle Dendroctonus (Coleoptera: Scolytidae) (Diaz et al. 2003). The intima layer in the proventriculus acts as the food grinder (Wigglesworth 1972). No proventriculus 
occurs in the haustellate insect such as in the fly Bactrocera dorsalis (Diptera: Tephritidae) (Lee et al. 1998).

\section{Midgut}

\section{Ventriculus}

The length of $N$. bosei worker midgut (Figure 2) was 3.86+0.61 mm, composed of only a region, the ventriculus. It was characterized by the occurrence of transitional epithelial cells and thin muscle cells. This was congruent with the result of Noirot and Noirot-Timothee (1969) that ventriculus has one cell type, the transitional epithelial cell, as the absorption and secretion cells. However, Nasutitermes takasagoensis worker ventriculus consisted of columnar cells (Tokuda et al. 2001). A variety of cell occurs in the Dendroctomts (Coleoptera: Scolytidae) ventriculus as well (Diaz et al. 2003).

The anterior ventriculus had a cardiac valve (Figure 6a), which was an imagination structure at the foregut towards the midgut. This structure was not found in the posterior ventriculus (Figure 6b). The cardiac valve covered the constricted region, hence it had low IP, OP, LA and GA values (Table 1).

Antiperistaltic movement was prevented by the cardiac valve, a constriction structure in the anterior ventriculus as shown in $N$. bosei. It prevented the food at the midgut to flow back to the foregut (Snodgrass 1935). This character was also reported in N. takasagoensis (Termitidae) (Tokuda et al. 2001). Hence, in termites and most other insects, the digested food always moves from anterior towards the posterior region of the alimentary canal.
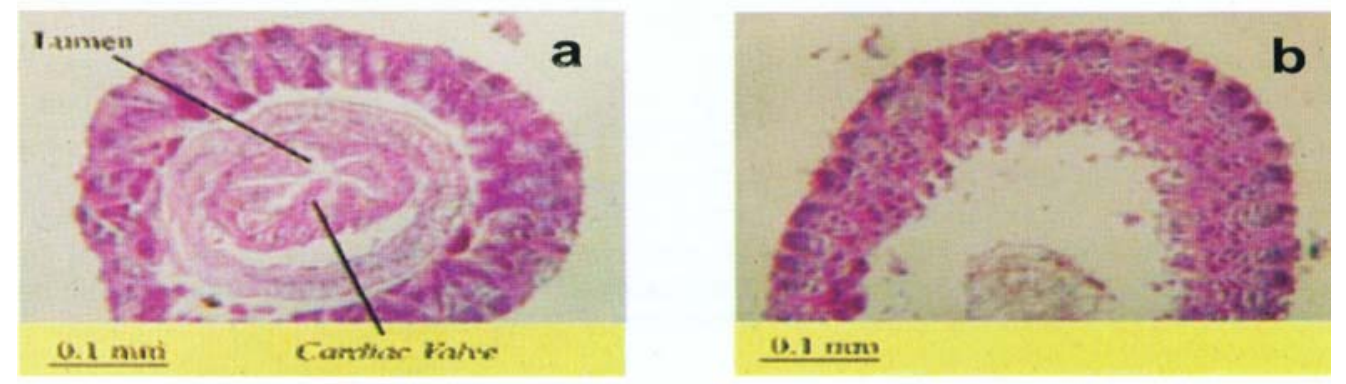

Figure 6. Ventriculus transversal section of $N$. bosei (a) anterior, (b) posterior region

There is no gastric caeca in the midgut of $N$. bosei worker; this structure is the same in $N$. takasagoensis worker (Tokuda et al. 2001). In most chewing insects, gastric caeca lays at the anterior region of the midgut (Romoser 1973) to enlarge the food absorption (Wigglesworth 1972). The absence of gastric caeca in worker termites showed an adaptation of termite digestion system as well. Termites do not 
need an additional space in the midgut for food absorption because the cellulose will be degraded subsequently in the hindgut, particularly in the rectum pouch.

\section{Hindgut}

The length of $N$. bosei worker hindgut was $6.56+0.91 \mathrm{~mm}$, composed of intima layer, columnar, transitional epithelial cells, and muscle cells. This alimentary canal region consisted of five parts, i.e. short channel that connected the mid- and the hindgut, enteric valve, rectum pouch, colon and the rectum.

\section{Short Channel}

This region could not be determined in the fresh alimentary canal, unless a histology preparation was made (Figure 7a, b). This is due to the similar diameter and the same color with that of ventriculus region. Short channel was covered with columnar epithelial cells and muscle layers (Figure 7b). Intima layer was not found in this region. The mean value of IP, OP, LA, and GA of these regions were shown in Table 1.

\section{Enteric valve}

Enteric valve was the second region in the hindgut constructed of three longitudinal folds facing towards the lumen, performed a clep structure (Figure 8a). It composed of intima layer, columnar epithelial cells, and muscle cells (Figure 8b). Mean of enteric valve OP was 0.530+0,039 mm (Table 1).
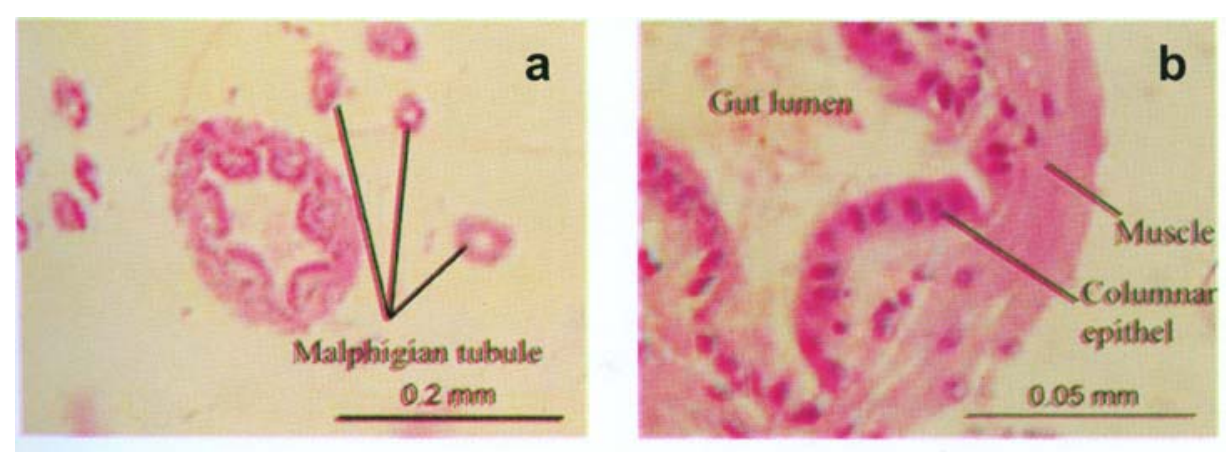

Figure 7. Tranversal section of the $N$. bosei short channel of hindgut

\section{Rectum Pouch}

The third part of the hindgut was the rectum pouch (Figure 9a), consisted of intima layer, transitional epithelial cells, and thin layer of muscle cells (Figure 9b,c). Rectum pouch had the largest OP value compared to others, that was $3.859+1.807 \mathrm{~mm}$. 


\section{Colon}

Colon was the fourth part in the hindgut region (Figure 10a,b), that composed of the same layers as shown in the rectum pouch. The OP value of $N$. bosei worker colon was $1.508+0.370 \mathrm{~mm}$.

\section{Rectum}

Rectum was the last part in the hindgut region (Figure 11) with a thick muscle layer. Other layers were the same as shown in the rectum pouch. There was no distinct region which separated the circular and longitudinal muscle layer, hence both were linked (Figure lib). The OP value of $N$. bosei worker rectum was $2.036+0.569 \mathrm{~mm}$, it was the largest OP diameter (see also Figure 2). This big pouch in termite hindgut is an important region as mentioned by Inoue et al. (2000), the hindgut harbours symbiotic flagellates which assist in cellulose digestion. Cellulose is a polimer of 5000 -10 000 anhidrid glucosa connected with $\mathrm{P}(\mathrm{l}, 4)$ glycoside (Feighl and Hill 1983). Most organism could not use $P(1,4)$ glycoside as the energy source. Those flagellates produce cellulase enzyme that degrade the cellulose into acetic acid, $\mathrm{CO}_{2}$, and $\mathrm{H}_{2}$. Hence, the enlargement of the termite hindgut is an adaptation mechanism of its behaviour and physiology.

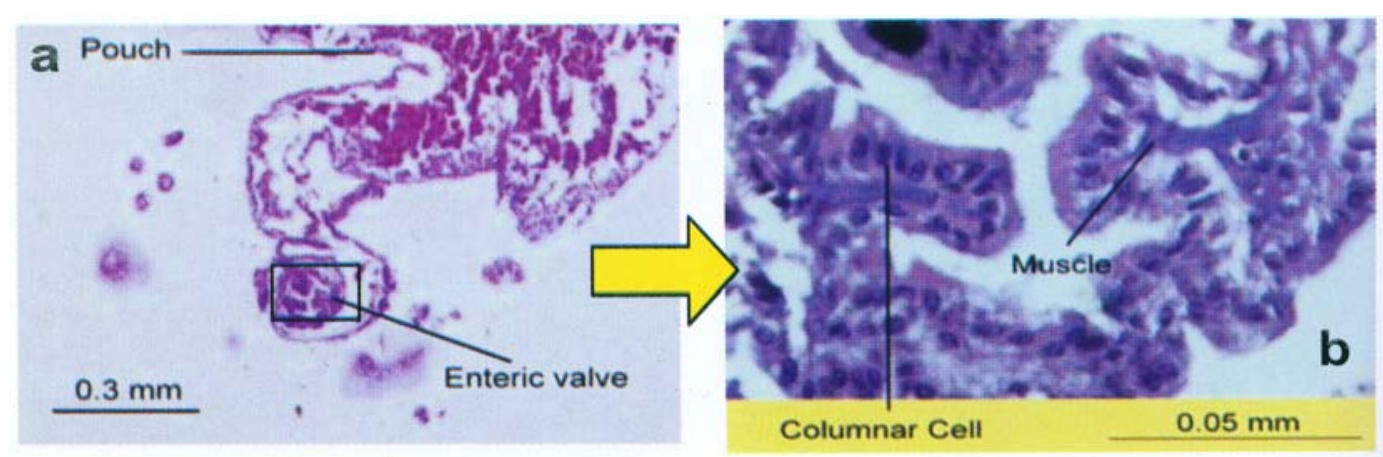

Figure 8. Enteric valve transversal section of $N$. bosei worker termite

Another difference of $N$. bosei worker to other termites is that it did not have a mixed segment. Mixed segment has a variety of histologic structures, located between the mid- and the hindgut. It is reported to exist in the Termitidae as an important character for identification (Bignell 1994).

In addition, the anatomy of $N$. bosei worker alimentary canal showed several differences compared to other insect alimentary canals. The hindgut of $N$. bosei worker was the longest region, which comprised $48 \%$ of the total length, whereas 24 and $28 \%$ for foregut and midgut, respectively. In most insects, the midgut is the longest part (Wigglesworth 1972) as shown in fruit fly Bactrocera dorsalis 

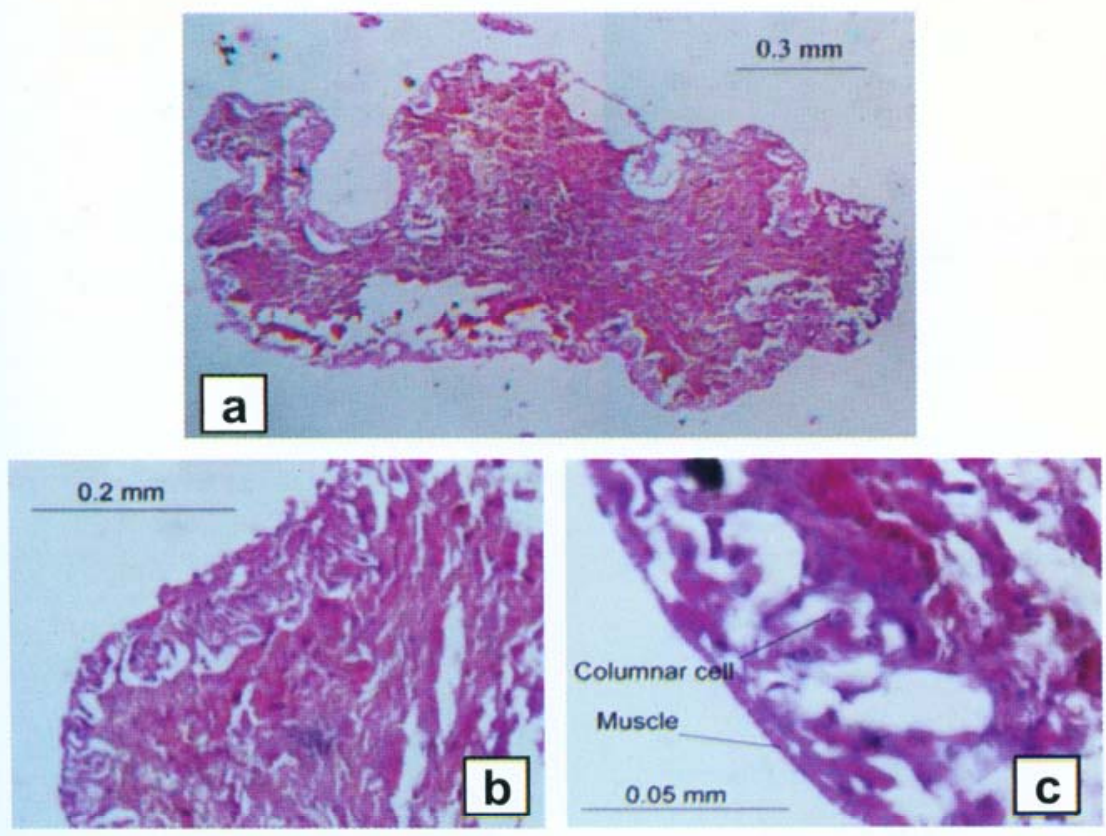

Figure 9. Rectum pouch transversal section of $N$. Bosei worker termite

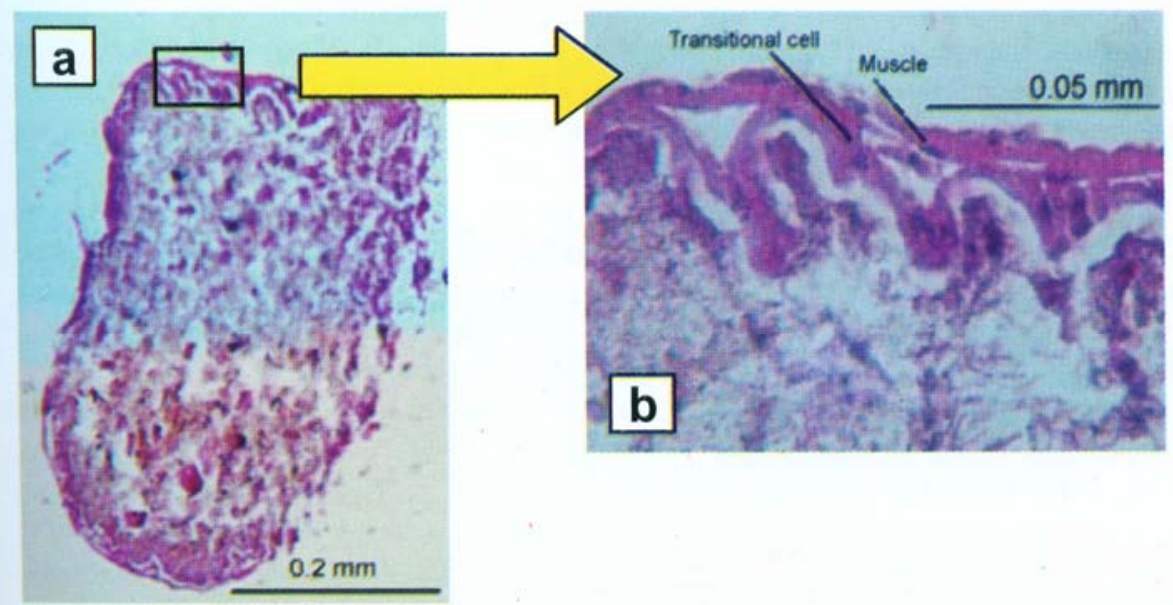

Figure 10. Colon transversal section of N.bosei worker termite 

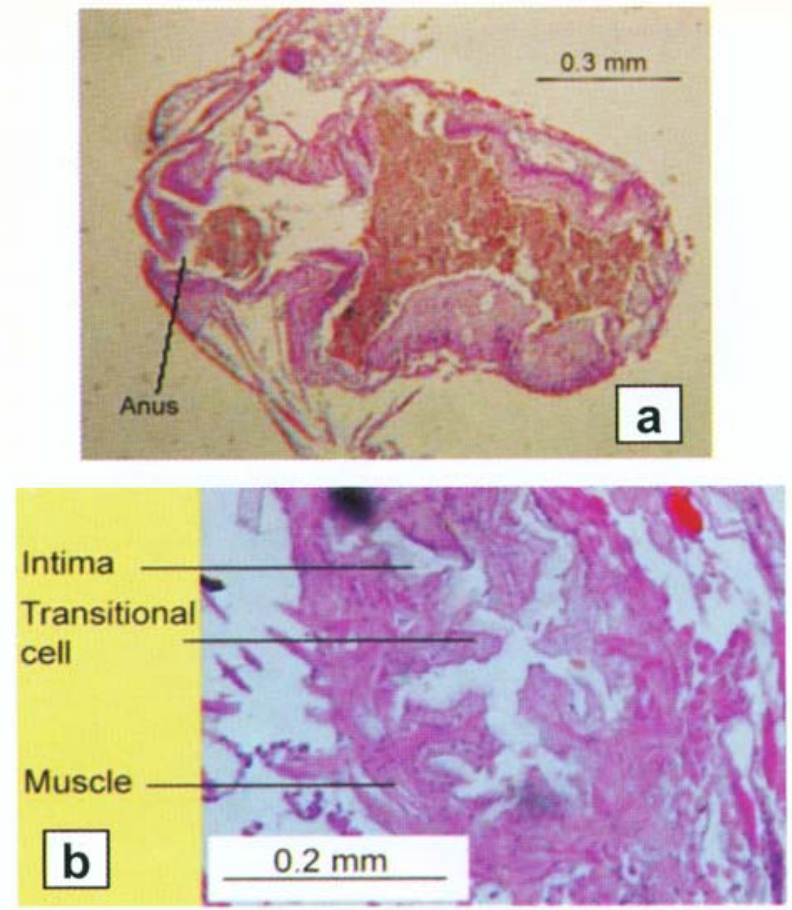

Figure 11. Longitudinal (a) and transversal section (b) of rectum in N. bosei worker termite

(Diptera: Tephritidae) (Lee et al. 1998; Hung et al. 2000) and moth larva, Hofmannophila pseudopretella (Lepidoptera: Oecophoridae) (Gerard 2002). In Dendroctonus (Coleoptera: Scolytidae) no difference in length among the fore-, mid-, and the hindgut were found (Diaz et al. 2003).

High variety value was observed in the outer and inner perimeter ratio (OP/IP). In most measurements, IP was higher than $\mathrm{OP}$, because large vili were facing to the lumen. However, at the crop, IP was lower than OP; this was due to the small vili size at the crop. IP was lower than OP which also occurred at the anterior ventriculus as well. This is due to the existence of cardiac valve.

Muscle thickness in $N$. bosei worker alimentary canal was varied as well. Thin muscle was found in oesophagus, ventriculus, and rectum pouch. This character showed that mechanic digestion was not a dominant process in those regions. Thin muscle in oesofagus helps the peristaltic movement to bring the food towards the crop (Snodgrass 1935; Elzinga 1978). In ventriculus there was no thick muscle which means that the cells did not digest the food mechanically. On the other hand, food had been mechanically digested in the proventriculus. 
The thick muscle layer occurred in the crop, proventriculus, and rectum. Food were mixed with saliva and stored in the crop (Wigglesworth 1972). Thus, the thick muscle layers in the crop were needed to enhance the muscle contraction to bring the food forward. In the proventriculus, the thick muscle layer together with six dentitions in the proventriculus ground the food. Moreover, the function of the thick layer in the rectum was to draw the feces out of the colon.

In future studies, we need to collect more information about the anatomy and histology of other termite caste of $N$. bosei alimentary canal, such as the soldier and reproductive castes. Then, one can make a comparative study among those termite castes and determine the conserve canal structure. One can also examines the plasticity of the structure(s), if any, due to the different behaviour and physiology of each termite caste. For example, soldiers termites obtain their food from the workers through trophalaxis. Based on the different types of food, do the crop of the soldier termites have the same histology structure as those of the workers?

This basic histology study will be fruitful as well for a further researches such as to examine the influence of several pesticide at the digestive canal of worker termites. One can see whether the pesticide is able to change the cells structure and intima layer covered the worker termites gut.

\section{CONCLUSIONS}

The total length of $N$. bosei alimentary canal was $13.71+1.28 \mathrm{~mm}$. The canal was divided into fore-, mid-, and hindgut which were 24,28 , and $48 \%$, respectively of gut total length. Two types of alimentary canal epithelial cells were found, i.e. the squamous and transitional cells. Areas covered with thick muscular tissue were crop, proventriculus, and rectum. Proventriculus was characterized with six large dentitions. There was no gastric caeca in $N$. bosei midgut which commonly occurred in chewing insect. Secretory cells were observed at proventriculus and ventriculus regions. Cardiac valve was found at the anterior end of ventriculus. Area with the largest outer perimeter was the rectum pouch. Enteric valve had three internal folds.

\section{REFERENCES}

AhmadM. 1965. Termites (Isoptera) of Thailand. Bull. Amer. Nat His. Suppl., 131: 33-195.

Bignell, D.E. 1994. Soil-feeding and gut morphology in higher termites. In: Hunt JH, Nalepa CA, editor. Nourishment and Evolution in Insect Societes. San Fransisco: Westview Pr. p 131-158. Borror D.J., Delong D.M.

and C.A. Triplehorn . 1981. An Introduction to the Study of Insects. 5th Ed. New York: CBS College Publ.

Chapman R.F. 1982. The Insects Structure and Function. 3rd Ed. Cambridge: Harvard Univ Pr. Claveland L.R. 1925. The feeding habit of termite castes and its relation to their intestinal flagellates. histological Biol. Bull., 48:295-308. Diaz E., Arciniega O., Sanchez L., Cisneros R, and G. Zuniga . 2003. Anatomical and comparison of the alimentary canal ofDendroctonus. Ann.Entomol. Soc. Am., 96:144-152. Dow J.A.T. 1986.

Insect midgut function. In: Tokuda G, Nakamura T. Murakami R, Yamoka I. 2001. Morphology of the digestive system in the wood-feeding termite Nasutitermes takasagoensis. Limited. Zool. Sci., 18:869-877. Elzinga R..J. 1978. Fundamentals of Entomology. New Delhi: Prentice Hall of India Private 
Emerson A.E. 1929. Communication among termites. In: Wilson EO. 1974. The Insect Societies.

Cambridge: The Belknap Univ Pr. Feighl D.M. and J.W. Hill. 1983. General, Organics, and Biological Chemistry.

2nd Ed. Edina: Burgess

Publ. Gerard P.J. 2002. The digestive system of the keratin-feeding larvae of Hofinannophila pseudospretella

(Lepidoptera: Oecophori-dae). New Zealand J. Zool., 29:15-22.

Gray P. 1952. Handbook of Basic Microtechnique. Philadelphia: The Blakiston Company. Hung C.N., Lin T.L. and W.Y. Lee

.2000. Morphology and ultrastructure of the alimentary canal of the oriental fruit fly Bacterocera dorsalis (Hendel) (Diptera: Tephritidae)(2): The structure of the midgut. Zool. Studies, 39: 387-394. Hungate R.E. 1939. Experiment on the nutrition of Zootermopsis (III) The

anaerobic carbohydrate

dissimilation by the intestinal protozoa. In: Mauldin JK, Smythe RV, Baxter CC. 1972. Cellulose

catabolism and lipid synthesis by the subterranean termite, Coplotermes formosanus. Insect

Biochem., 2: 209-217. Inoue T., Kitade O., Yoshimura T. and T. Yamoka . 2000. Symbiotic association with

protist. In: Abe T,

Bignell DE, Higashi M, editor. Termites: Evolution, Sociality, Symbioses, Ecology. Dordrecht:

Academic Publ., p. 275-288. Krishna K. 1969. Introduction. In: Krishna K, Weesner FM, editor. Biology of

Termites. Vol 1. New

York: Acad Pr., p. 1-17. Lange A..B. and I. Orchard . 1998. The effects of SchistoFLRFamide on contractions of locust midgut.

canal of the Peptides 19:459-467. Lee W.Y., Chen M.E. and T.L.Lin. 1998. Morphology and ultrastructure of the alimentary

oriental fruit fly Bacterocera dorsalis (Hendel) (Diptera: Tephritidae)(l): The structure of the foregut and cardia. Zool. Studies, 37:95-101. McFarlane. Nutrition and digestive organs. In: Blum MS, editor. Fundamentals of Insect Physiology.

New York: John Wiley and Sons. McMahan E.A. 1969. Feeding relationship and radioisotope techniques. In:

Krishna K, Weesner FM, editor. Biology of Termites. Volume ke-1. New York: Academic Pr., P. 1-17. Miller A. 1965. The internal anatomy and histology of the imago of Drosophila melanogaster. In: Demerec M, editor Biology of Drosophila. New York: Hafner Publ Co., p. 425-439. Noirot C.H. and C. NoirotTimothee . 1969. The digestive system. In: Krishna K, Weesner FM, editor. Biology of Termites. Volume ke-1. New York: Academic Pr., p .49-88. Ribbands C.R. 1953. The behaviour and social life of honeybees. In: Wilson EO. 1974. The Insect Societies. Cambridge: The Belknap Univ Pr.

Romoser W.S. 1973. The Science of Entomology. New York: Macmillan Publ Co, Inc. Sheffrahn R.H. and N.Y. Su . 1994. Keys to soldier and winged adult termites (Isoptera) of florida. Florida Entomologist, 77:460-470.

Snodgrass, R.E. 1935. Principles of Insect Morphology. New York: McGraw-Hill Book Company, Inc. Stuart A.M. 1969. Social behaviour and communication. In: Krishna K, Weesner FM, editor. Biology of Termites. Vol 1. New York: Academic Pr., p. 193-232. Tokuda G., Nakamura T., Murakami R. and I. Yamoka I. 2001. Morphology of the digestive system in the wood-feeding termite Nasutitermes takasagoensis. Zool. Sci., 18:869-877. Wigglesworth V.B. 1972. The Principles of Insect Physiology. London: Chapman and Hall. Wilson E.O. 1965. Chemical communication in the social insects. In: Wilson EO. 1974. The Insect Societies. Cambridge: The Belknap Univ Pr. Wilson E.O. 1974. The Insect Societies. Cambridge: The Belknap Univ Pr. 